\title{
DEISGN OF MULTI-VILLAGE RURAL WATRE SUPPLY SYSTEM
}

\author{
Survase Niteen Madhukar \\ Department of Civil Engineering \\ SGGS Institute of Engineering and Technology, \\ Vishnupuri, Nanded (M.S.), India
}

\begin{abstract}
Water supply in India is now broadcast as community based demand driven system, under which it's important to reinforce capacity of local community exist in village and small town to improve and manage their own water supply system. The drinking water is one among the essential elements required for all components to hold out the various fundamental activities of lifecycle. Due to rapid urbanization and water inadequacy, continuing a stable and safe water supply has become a challenge to many cities. To overcome these challenges water supply system is required. Basics of Water Supply System gives information on the basic modules of a water supply system, as well as their installation, operation, and distribution, as well as drinking water quality management. With the use of digital GPS, a study of the current population, population from the last three decades, daily water demand, flow characteristics, and a survey of the village are conducted for the proposal of a water supply system. The towns' water supply network is analysed and developed using Bentley's WATERCAD programme. Water distribution network systems are designed to distribute water from a source to all or any single user in a sufficient amount, quality, and pressure.
\end{abstract}

Keywords- Water Supply System, Water distribution Network, WATERCAD, Rural Area, Population Forecast, Water Demand.

\section{INTRODUCTION}

\subsection{General}

A good water supply plan is necessary for a civilised community and to keep people fit. Following an assessment of the population's water requirements for various uses, a water delivery network will be built to provide water to the population as needed. A water delivery plan must provide potable water that is free of any defects that could cause water-borne diseases. The provision of safe and sufficient water is critical for a healthy lifestyle. Without water, a clean and safe environment is impossible to envisage. In truth, water is essential for all living things, and water intended for human use must be both safe and sufficient to meet all necessary requirements. A water supply system is a system that collects, transports, treats, stores, and distributes water from a source to customers, such as

\author{
DR.M.L.Waikar \\ Department of Civil Engineering \\ SGGS Institute of Engineering and Technology, \\ Vishnupuri, Nanded (M.S.), India
}

households, businesses, industries, irrigation facilities, and government organisations.

\subsection{Historical Development}

In 1960, the Ministry of Health established a National Water Supply and Sanitation Committee to examine the development of the National Water Supply and Sanitation Program and to accurately analyse urban and rural needs. According to the assessment of this committee, India's 60 percent towns only cover 6.5 percent of the total population. Only 48.5 percent of the population had access to safe drinking water, which ranged from 10 to 150 litres per capita per day. Water supply and sewerage were allocated Rs.339 crores in the fourth five-year plan. A number of water supply and sewerage schemes have been completed, as well as a number of schemes to eliminate water-borne diseases. A total of Rs. 100 crores has been set up for water supply initiatives in rural regions where there is a severe scarcity. There was always a scarcity of funds in India for its many programmes. Despite these efforts, spending on water supply and sanitation accounts for less than $3 \%$ of total plan spending, which is a reasonable proportion. After paying such sums, India's urban population of 85 percent receives safe drinking water. However, in rural regions, more work needed to ensure that the populace has access to safe drinking water.

\subsection{Necessity for Planned Water Supplies}

There is always a need for water, no matter where we are. Water is required everywhere, from our homes to schools, companies, hotels, and restaurants. Water is required in many forms, quantities, and qualities, regardless of whether it is a hamlet, town, or metropolis. Water is what keeps us safe from contamination in the environment. As a result, the water we require should be readily available and tailored to our needs. Water quality requirements range for agricultural, household, institutional, and industrial purposes. As a result, in order to make water available, we must first understand the goal, then the amount, and finally the quality. Agriculture, residential use, and industrial use may all require water. And the quality of the water to be used varies for each of the above. As an engineer, we may be required to prepare for water for agricultural purposes, and irrigation engineers are responsible for this. A public health engineer must plan the water supply and distribution system for home and community water needs. 


\section{International Journal of Engineering Applied Sciences and Technology, 2021 \\ Vol. 6, Issue 4, ISSN No. 2455-2143, Pages 107-114 \\ Published Online August 2021 in IJEAST (http://www.ijeast.com)}

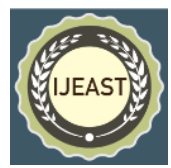

Industrial and civil engineers must plan the requirements for an industrial usage.

1.4 Objectives

1. To plan and design an integrated water supply system.

2. To supply water equitably to the consumers with sufficient pressure.

3. To identify the possible water sources.

4. To determine the water demand

5. To design the components of the water supply system, such as the pipe network, transmission and distribution system, and storage reservoir sizing.

6. To analyse the water distribution system using WaterCAD.

\section{RELATED WORK}

"In this study, the existing water distribution system is simulated through construct of a model using Bentley Water GEMS. It helped in analyzing the whole network system, visualized the consequences of constituent components and parameters also beacause the pressure at end node is detected low, that shows the consumer near the reservoir having more advantages of water than the one that resides away from the reservoir" ( Dilip Babubhai Paneria 2017)

"The Water distribution network plays vital role in supplying water to last user. Water GEMS is hydraulic modeling software which is useful for analysis and design of water distribution network. The result obtained verified that the pressure at all junction and therefore the flows with their velocities at all pipes are feasible enough to supply adequate water to the network of study area. The end result will help to understand the pipelines system of the study area in a better way. At the end of the analysis it had been found that the resulting pressure at all nodes and therefore the flows with their velocities" (Prashant Virjibhai Vaghela 2010)

"Design of water supply system duly considering optimization in addition to the cost minimization, minimum head requirement and minimum chlorine requirement is presented" Sajedkhan S. Pathan (2015)

It is observed in the literature that there are many topics related to the design, operation, reliability and maintenance of water distribution system. The hydraulic analysis and pump scheduling performance have been studied in a number of ways. According to studies, the majority of the water is lost due to pipeline leaks. WATERCAD software can be used to solve difficulties with water distribution systems.

\section{STUDY AREA AND DATA COLLECTION}

\subsection{General}

According to Census 2011 information the location code or village code of Bhageya village is 367420 .

Bhageya village is located in Balumath Tehsil of Latehar district in Jharkhand, India. It is situated $64 \mathrm{~km}$ away from district headquarter Balumath. Balumath is the sub-district headquarter of Bhageya village. It is located $25 \mathrm{~km}$ away from Block. As per 2009 stats, Bhageya is the gram panchayat of Bhageya village. Bhageya is surrounded by Chandwa Block towards South, Lawalong Block towards North, Tandwa Block towards East, Latehar Block towards west. Churi, Chatra, Lohardaga, Patratu are the nearby Cities to Bhageya.

Bhageya is a Village in Balumath Block in Latehar District of Jharkhand State, India. It is located $64 \mathrm{KM}$ towards East from District headquarters Latehar. 22.9 Km from Balumath Block. Nearest water source is Damodar River. Where the parameter $\alpha$ is called embedding intensity and their effect of validity of the algorithm directly is apply after this process, after that apply the inverse wavelet transform to the image for find out watermark image.

The following are the longitude, latitude \& elevation:

$\begin{array}{lll}\text { a) } & \text { Longitude } & : 84^{\circ} 56^{\prime} 38.38^{\prime \prime} \mathrm{E} \\ \text { b) } & \text { Latitude } & : 23^{\circ} 43^{\prime} 12.21^{\prime \prime} \mathrm{N} \\ \text { c) } & \text { Elevation } & : 471 \mathrm{~m}\end{array}$

\subsection{Existing Status of Water Supply}

There is no existing water supply scheme in operation for these villages. Hence there is a need to provide water supply scheme to this rapidly developing area. In all other villages people are getting water from hand pump \& private wells in the nearby vicinity of the village.

From the population figures, it can be seen that the growth of population is rapid. Present water supply condition is not at all sufficient to cater the need of water for this fast developing area. Hence, these habitations have been included in the list of priority villages and new scheme is needed to be proposed.

\subsection{Data Collection}

\begin{tabular}{|c|l|c|c|c|}
\hline \multirow{2}{*}{ Sr. No. } & \multirow{2}{*}{ Village } & \multicolumn{3}{|c|}{ Year } \\
\cline { 3 - 5 } & & $\mathbf{1 9 9 1}$ & $\mathbf{2 0 0 1}$ & $\mathbf{2 0 1 1}$ \\
\hline 1 & Bhageya & 1325 & 1513 & 2242 \\
\hline 2 & Keri & 1245 & 1409 & 2199 \\
\hline 3 & Okea & 1005 & 1349 & 1717 \\
\hline 4 & Siram & 779 & 1007 & 1770 \\
\hline 5 & Santi & 659 & 750 & 1091 \\
\hline 6 & Murpa & 1839 & 2351 & 3143 \\
\hline 7 & Balbal & 250 & 330 & 433 \\
\hline 8 & Jipua & 959 & 1180 & 1565 \\
\hline 9 & Mausingha & 834 & 1150 & 1182 \\
\hline 10 & Chandli & 152 & 237 & 450 \\
\hline 11 & Marangloiya & 1056 & 1242 & 1743 \\
\hline 12 & Bara & 488 & 706 & 880 \\
\hline 13 & Jilinga & 698 & 866 & 1107 \\
\hline 14 & Ganeshpur & 2137 & 2698 & 3342 \\
\hline 15 & Chamatu & 913 & 1178 & 1606 \\
\hline 16 & Seregara & 2248 & 2904 & 3680 \\
\hline & TOTAL & $\mathbf{1 6 5 8 7}$ & $\mathbf{2 0 8 7 0}$ & $\mathbf{2 8 1 5 0}$ \\
\hline
\end{tabular}



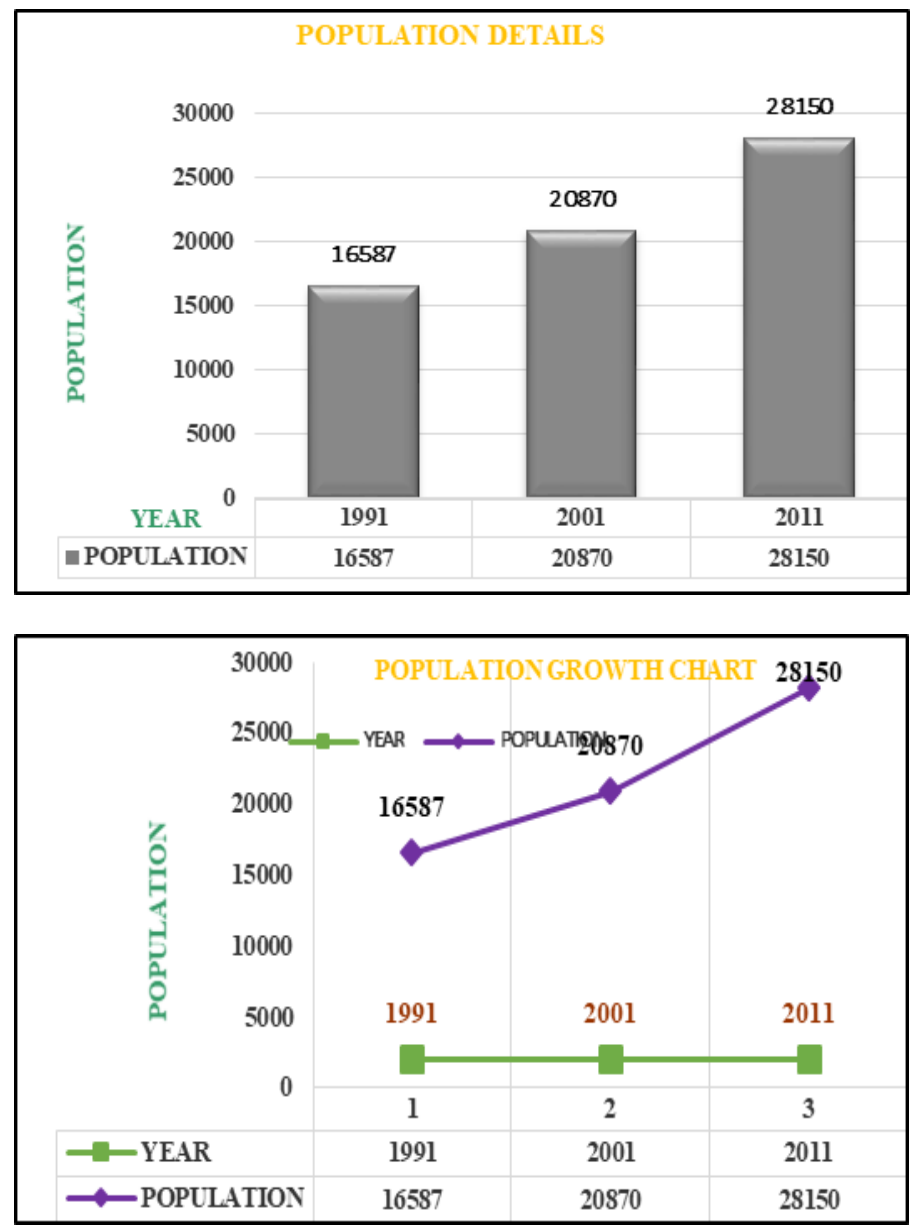

\section{METHODOLOGY}

\subsection{Population Forecasting Methods}

After deciding the design period, the population of a village or town must be determined. Births, deaths, migration, and annexation all affect the population of a village. The village's future growth is mostly dependent on commerce expansion, business development, and the surrounding republic. Mine discoveries, railway station building, and other factors may result in quick increases, gradual growth, and stationary conditions, or even population loss. For population forecasting, it is preferable to look at the growth of other similar villages that have grown under similar conditions, because the expected village will grow along similar lines.

The following are the commonly used methods for population forecasting.

1. Arithmetical Increase Method

2. Geometrical Increase Method

3. Incremental Increase Method

4. Decrease Rate of Growth Method
1) Arithmetical Increase Method:-

This method is predicated on the assumption that population growth will remain constant. Over time, the population growth rate has been steady.

The population after ' $n$ ' decades can be determined by the formula.

$$
\mathrm{Pn}=\mathrm{P}+\mathrm{n} \times \mathrm{C}
$$

Where, $\mathrm{Pn} \quad=\quad$ Population after nth decades

$\begin{array}{lll}\mathrm{P} & = & \text { Present Population } \\ \mathrm{C} & = & \text { Average decade increase } \\ \mathrm{n} & = & \text { number of decades }\end{array}$

2) Geometrical Increase Method:-

This technique is predicated on the assumption that population growth rates remain stable over time. This method is used to establish the average percentage of increase during the last few decades, and population forecasting is based on the premise that the percentage rise per decade will remain constant.

The population at the end of ' $n$ ' decades is calculated by

$$
\mathrm{Pn}=\mathrm{P}[1+(\mathrm{Ig} / 100)]^{\wedge} \mathrm{n}
$$

Where, Pn = Population at the end of nth decade

$\begin{array}{ll}\mathrm{P} & = \\ \mathrm{Ig} & = \\ \mathrm{n} & =\end{array}$

Present Population

Average Geometric Growth Mean number of decades

3) Incremental Increase Method:-

This method is superior to the previous two. The arithmetical approach is used to calculate population growth, and the average of the net incremental increase is added once for each subsequent decade.

The Population after nth decade

$$
\mathrm{Pn}=\mathrm{P}+\mathrm{nX}+[\mathrm{n}(\mathrm{n}+1) / 2] \times \mathrm{Y} .
$$

Where, Pn = Population after nth decade

$\begin{array}{lll}\mathrm{P} & = & \text { Present Population } \\ \mathrm{n} & = & \text { number of decades } \\ \mathrm{X} & = & \text { Average Decade Increase } \\ \mathrm{Y} & = & \text { Average Incremental Increase }\end{array}$

4) Decrease Rate of Growth Method:-

All life has been found to grow in a finite quantity of space. If the complete growth of a very old town is shown, the curve will have an S-shape, suggesting that early growth happens at a faster rate than later growth, signalling that the saturation limit has been achieved. The average decline in percentage increase is calculated and then removed from the most recent percentage increase for each subsequent decade in this manner.

Population after nth decade 
$\mathrm{Pn}=\mathrm{P}(1+\mathrm{R})^{\wedge} \mathrm{n}$

$\begin{array}{rll}\text { Where, } \mathrm{P} & = & \text { Present Population } \\ \mathrm{n} & = & \text { number of decades } \\ \mathrm{R} & = & \text { Growth Rate in Percentage }\end{array}$

\subsection{Water Demand}

When planning a water supply strategy for a village or town, it's important to figure out how much water the town would need for various reasons. In fact, the engineer's first task is to assess the village's water demand and then to identify appropriate water sources from which the need may be satisfied. However, because the demand for water is influenced by so many factors, it is impossible to correctly predict the real need. The water demand is determined using empirical formulae and thumb rules, and It is fairly accurate in terms of actual demand.

The various types of water demands are listed below.
i. Domestic water demand
ii. Industrial demand
iii. Institution and commercial demand
iv. Demand for public use
v. Fire demand
vi. Loses and wastes

\subsection{TOTAL REQUIREMENT OF WATER FOR A VILLAGE}

The issue regarding per capita rate of water supply has been discussed. It has been decided in the discussions that the rate of water supply should be $55 \mathrm{lpcd}$. As a result, based on the estimated population, the Water Delivery System will be designed for a 55 lpcd water supply rate and flows in the design year. The design flow is computed by projecting the current population for the design year using population projection statistics and an expected lpcd rate.

According to the CPHEEO guideline, water demand forecasts are done with a per capita rate of $55 \mathrm{lpcd}$ at the consumer end and $15 \%$ losses for gross demand (Total $65 \mathrm{lpcd}$ ) projections.

\begin{tabular}{|l|l|l|l|l|l|c|c|c|}
\hline S & \multirow{2}{*}{ Villag } & \multicolumn{4}{|c|}{ Population } & \multicolumn{3}{|c|}{ Demand } \\
\cline { 3 - 9 } r. & $\begin{array}{c}\text { e } \\
\text { N }\end{array}$ & $\mathbf{2 0}$ & $\mathbf{2 0}$ & $\mathbf{2 0}$ & $\mathbf{2 0}$ & $\mathbf{2 0 2}$ & $\mathbf{2 0 3}$ & $\mathbf{2 0 5}$ \\
name & $\mathbf{1 1}$ & $\mathbf{2 1}$ & $\mathbf{3 6}$ & $\mathbf{5 1}$ & $\mathbf{1}$ & $\mathbf{6}$ & $\mathbf{1}$ \\
\hline \multirow{2}{*}{1} & Bhage & 22 & 23 & 27 & 31 & 0.1 & 0.1 & 0.2 \\
& ya & 42 & 69 & 95 & 27 & 540 & 817 & 033 \\
\hline \multirow{2}{*}{2} & Keri & 21 & 23 & 28 & 31 & 0.1 & 0.1 & 0.2 \\
& & 99 & 86 & 15 & 50 & 551 & 830 & 047 \\
\hline
\end{tabular}

\begin{tabular}{|c|l|c|c|c|c|c|c|c|}
\hline \multirow{2}{*}{3} & \multirow{2}{*}{ Okea } & 17 & 14 & 17 & 19 & 0.0 & 0.1 & 0.1 \\
& & 17 & 83 & 50 & 58 & 964 & 137 & 272 \\
\hline \multirow{2}{*}{4} & \multirow{2}{*}{ Siram } & 17 & 17 & 20 & 23 & 0.1 & 0.1 & 0.1 \\
& & 70 & 57 & 73 & 19 & 142 & 348 & 508 \\
\hline \multirow{2}{*}{5} & \multirow{2}{*}{ Santi } & 10 & 11 & 13 & 15 & 0.0 & 0.0 & 0.0 \\
& & 91 & 51 & 58 & 19 & 748 & 883 & 988 \\
\hline \multirow{2}{*}{6} & \multirow{2}{*}{ Murpa } & 31 & 35 & 42 & 47 & 0.2 & 0.2 & 0.3 \\
& & 43 & 65 & 07 & 06 & 317 & 734 & 059 \\
\hline \multirow{2}{*}{7} & \multirow{2}{*}{ Balbal } & 43 & 53 & 62 & 70 & 0.0 & 0.0 & 0.0 \\
& & 3 & 2 & 8 & 2 & 346 & 408 & 456 \\
\hline \multirow{2}{*}{8} & \multirow{2}{*}{ Jipua } & 15 & 15 & 18 & 20 & 0.1 & 0.1 & 0.1 \\
& & 65 & 76 & 60 & 80 & 024 & 209 & 352 \\
\hline \multirow{2}{*}{9} & Mausi & 11 & 17 & 21 & 23 & 0.1 & 0.1 & 0.1 \\
& ngha & 82 & 99 & 23 & 75 & 169 & 380 & 544 \\
\hline 1 & Chand & 45 & 70 & 83 & 93 & 0.0 & 0.0 & 0.0 \\
0 & li & 0 & 7 & 4 & 3 & 460 & 542 & 607 \\
\hline 1 & Maran & 17 & 17 & 21 & 23 & 0.1 & 0.1 & 0.1 \\
1 & gloiya & 43 & 96 & 19 & 71 & 167 & 378 & 541 \\
\hline 1 & \multirow{2}{*}{ Bara } & 88 & 10 & 11 & 13 & 0.0 & 0.0 & 0.0 \\
2 & & 0 & 16 & 99 & 41 & 660 & 779 & 872 \\
\hline 1 & \multirow{2}{*}{ Jilinga } & 11 & 10 & 12 & 13 & 0.0 & 0.0 & 0.0 \\
3 & & 07 & 21 & 05 & 48 & 664 & 783 & 876 \\
\hline 1 & Ganes & 33 & 37 & 43 & 48 & 0.2 & 0.2 & 0.3 \\
4 & hpur & 42 & 10 & 78 & 97 & 412 & 846 & 183 \\
\hline 1 & Chama & 16 & 17 & 21 & 23 & 0.1 & 0.1 & 0.1 \\
5 & tu & 06 & 89 & 11 & 61 & 163 & 372 & 535 \\
\hline 1 & Serega & 36 & 35 & 41 & 46 & 0.2 & 0.2 & 0.3 \\
6 & ra & 80 & 10 & 42 & 33 & 282 & 692 & 012 \\
\hline \multirow{2}{*}{ Total } & $\mathbf{2 8}$ & $\mathbf{3 0}$ & $\mathbf{3 5}$ & $\mathbf{3 9}$ & $\mathbf{1 . 9}$ & $\mathbf{2 . 3}$ & $\mathbf{2 . 5}$ \\
& & $\mathbf{0}$ & $\mathbf{7}$ & $\mathbf{7}$ & $\mathbf{8 2}$ & $\mathbf{6 0 9}$ & $\mathbf{1 3 8}$ & $\mathbf{8 8 3}$ \\
\hline
\end{tabular}

\subsection{WATERCAD SOFTWARE FOR DITRIBUTION SUSYTEM}

WaterCAD is a water distribution system hydraulic and water quality modelling application that is simple to use. It is a decision-support tool for water infrastructure that is dependable, resource-saving, and easy to use. WaterCAD helps to study, design, and optimise water distribution systems, from fire flow and water quality studies to energy cost management and pump modelling.

\section{Streamlined model building}

The free LoadBuilder and TRex geographic modules allow you allocate water demands and node elevations based on geospatial data contained in shapefiles, DEMs, and even CAD drawings, minimising potential manual-input errors and speeding up the model-building process. We can also generate hydraulically connected models directly from CAD drawings, integrate topology and data from GIS, and create durable, bidirectional 


\section{International Journal of Engineering Applied Sciences and Technology, 2021 \\ Vol. 6, Issue 4, ISSN No. 2455-2143, Pages 107-114 \\ Published Online August 2021 in IJEAST (http://www.ijeast.com)}

links between shapefiles, databases, spreadsheets, and the WaterCAD model.

2. Water quality modelling

The built-in water quality features assist you in developing comprehensive chlorination schedules, simulating emergency contamination events, visualising zones of effect for diverse water sources, and improving turbidity, taste, and odour by recognising water blending problems in the system.

3. Critical analysis and operations modelling

The Key Analysis is a powerful tool for identifying critical assets in water distribution infrastructure and assessing the risk of their failure. Engineers can also detect operational bottlenecks, reduce energy usage, and simulate real-time operations to optimise system performance by applying rulebased operational controls, variable-speed pumping (VSP), and pressure-dependent demands (PDD).

\section{RESULT}

5.1 Design Parameters for Water Supply Scheme

5.1.1 Design Year:

$\begin{array}{lll}\text {-Initial Stage } & : & 2021 \\ \text {-Intermediate Stage } & : & 2036 \\ \text {-Ultimate Stage } & : & 2051\end{array}$

Hence the ultimate design year to be considered for the Project is 2051.

5.1.2 Water Demand:

According to the CPHEEO guideline, water demand forecasts are done with a per capita rate of $55 \mathrm{lpcd}$ at the consumer end and $15 \%$ losses for gross demand (Total $65 \mathrm{lpcd}$ ) projections.

5.1.3 Hours of Pumping:

By analyzing the power availability situation, we have decided to design the Rising mains, Pumping machinery, water treatment plant considering 16 hours pumping per day.

5.1.4 Hazen-Williams C-Value:

The following $\mathrm{C}$-values would be used for distribution system design based on the material and age of the pipe.

Table : 1- Hazen Williams C - Value For Different Pipe Materials (Distribution Pipes)

\begin{tabular}{|l|c|c|}
\hline \multirow{2}{*}{\multicolumn{1}{|c|}{ Material }} & \multicolumn{2}{c|}{ C Value } \\
\cline { 2 - 3 } & New Pipes & Design Purpose \\
\hline Cast Iron (CI) & 130 & 100 \\
\hline Asbestos Cement & 150 & 140 \\
\hline Ductile Iron (DI) & 140 & 140 \\
\hline Mild Steel (Mortar Lined) & 130 & 110 \\
\hline PVC, GRP, HDPE pipes & 150 & 145 \\
\hline
\end{tabular}

5.1.5 Water Treatment Plant:

The source for the water supply scheme is River i.e. surface water. We propose Conventional water treatment plants with units such as aeration fountain, flash mixer, Clarifloculator, rapid sand filter and chlorination arrangement.

\subsubsection{Service Reservoirs:}

The minimum service or balancing capacity is determined by the number of hours and rate of pumping each day, as well as the likely variance in demand or consumption over the course of the day and the hours of supply. The mass diagram can be used to calculate the capacity. After the distribution system design, which will supply elevation of ESRs, the staging height of the Elevated service reservoir can be fixed.

\subsubsection{Peak Factor for Distribution System Design}

In terms of distribution system design, it is the hourly variation in consumption that matters. To account for demand changes, the peak rate of consumption (which is equal to the average rate multiplied by the peak factor) is used as the rate of flow in the distribution system design.

CPHEEO's manual recommendations for peak factors are as below:

\begin{tabular}{|c|l|c|}
\hline $\begin{array}{c}\text { Sr. } \\
\text { No. }\end{array}$ & \multicolumn{1}{|c|}{ Description } & $\begin{array}{c}\text { Peak } \\
\text { Factor }\end{array}$ \\
\hline 1 & For population less than 50,000 & 3.0 \\
\hline 2 & For population range of 50,000 to 2,00,000 & 2.5 \\
\hline 3 & For population more than 2,00,000 & 2.0 \\
\hline 4 & For small Water Supply Scheme & 3.0 \\
\hline
\end{tabular}

\subsubsection{Residual Pressures in the Distribution System:}

As the project area is rural area, at the consumer end, the system is designed for a minimum residual pressure of $7 \mathrm{~m}$.

\subsubsection{Minimum Diameter of the Pipe:}

Pipes with a minimum diameter of $100 \mathrm{~mm}$ are proposed for the analysis.

\subsection{PROPOSED WATER SUPPLY SYSTEM}

\subsubsection{Intake Arrangement:}

The intake arrangement is located on the right bank of the Damodar River. It consist of the following sub works:

- Intake Well and Pump House :

It is proposed to construct $5.0 \mathrm{~m}$ Dia. R.C.C. Intake well and overhead Pump House at bank of Damodar River. The bottom level is kept as $431.565 \mathrm{~m}$, which is $1.65 \mathrm{~m}$ deeper than the suction level. The plinth of the Intake well is kept as $441.500 \mathrm{~m}$ which is about $1 \mathrm{~m}$ above the High flood level. The pump house is proposed over the Intake well, which will accommodate the raw water VT pumps and the panel boards. It will have $5.0 \mathrm{~m}$ height.

- Approach Bridge: Length of approach bridge = $24 \mathrm{M}$ 
International Journal of Engineering Applied Sciences and Technology, 2021

Vol. 6, Issue 4, ISSN No. 2455-2143, Pages 107-114

Published Online August 2021 in IJEAST (http://www.ijeast.com)

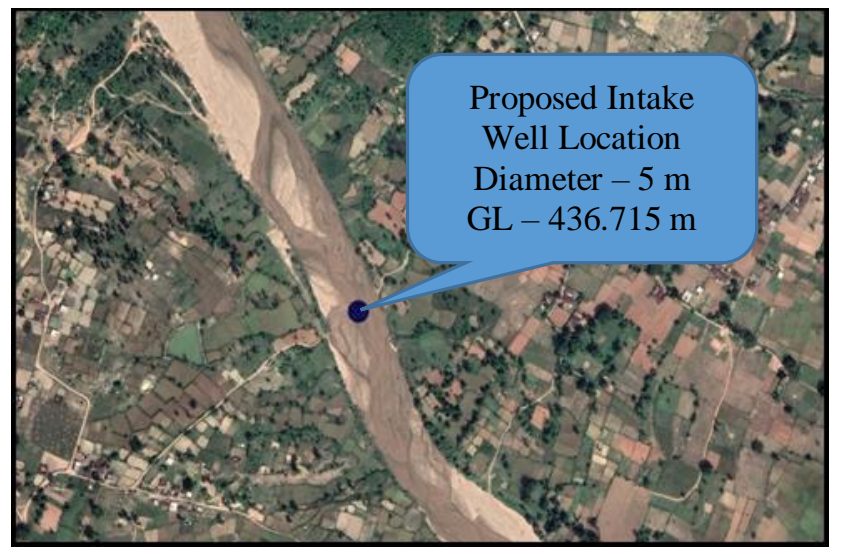

5.2.2 Water Treatment Plant:

Conventional Water Treatment Plant is proposed to be constructed at about $3295 \mathrm{~m}$ from source. It will have 3.50 MLD capacity. It has been designed for intermediate stage as per the guidelines of CPHEEO's manual.

The Conventional Water Treatment Plant will have following units.

1. Aeration Fountain.

2. Flash Mixer

3. Clariflocculator

4. Chemical House

5. Rapid sand Filter

6. Laboratory cum office room

7. Chlorinator

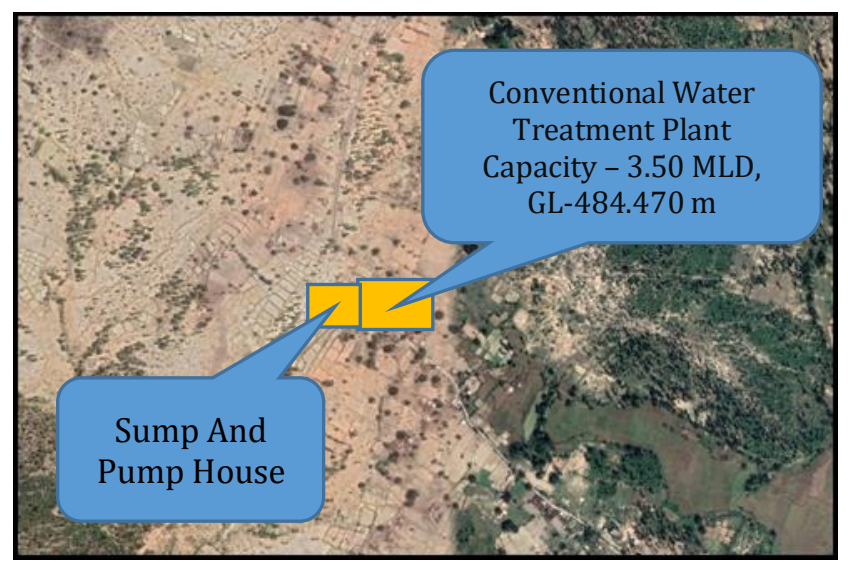

5.2.3 Raw Water and Pure Water Pumping Machinery: (Considering 16hrs Pumping)

\begin{tabular}{|c|l|c|c|}
\hline $\begin{array}{c}\text { Sr. } \\
\text { No. }\end{array}$ & \multicolumn{1}{|c|}{ Description } & $\begin{array}{c}\text { Raw Water } \\
\text { Pumping } \\
\text { Machinery }\end{array}$ & $\begin{array}{c}\text { Pure Water } \\
\text { Pumping } \\
\text { Machinery }\end{array}$ \\
\hline 1 & $\begin{array}{l}\text { Location of } \\
\text { Pumping } \\
\text { Machinery }\end{array}$ & $\begin{array}{c}\text { At Intake } \\
\text { Well }\end{array}$ & At WTP \\
\hline 2 & Pump Type (Nos) & $\begin{array}{c}\text { VT } \\
(1 \mathrm{~W}+1 \mathrm{~S})\end{array}$ & $\mathrm{CF}(1 \mathrm{~W}+1 \mathrm{~S})$ \\
\hline 3 & Horse Power & $65 \mathrm{HP}$ & $140 \mathrm{HP}$ \\
\hline 4 & Discharge & $144613 \mathrm{LPH}$ & $144613 \mathrm{LPH}$ \\
\hline 5 & Head & $69 \mathrm{~m}$ & $131 \mathrm{~m}$ \\
\hline
\end{tabular}

\subsubsection{Design of Raw Water and Pure Water Rising Mains:}

Design of this Raw Water Rising main with water hammer calculations and economical size of Pipe Diameter.

1. Raw water Rising Main has been proposed from Intake well to Water Treatment Plant. It consist of $250 \mathrm{~mm}$ dia. DI K-9 pipeline and length $3295 \mathrm{~m}$.

Design of this Pure Water Rising main is proposed from sump and pump house near Water Treatment Plant.

1. From Node -1 to GSR at Seregara (Zone-3): - Diameter proposed is $150 \mathrm{~mm}$ DI K-9 having $10524 \mathrm{~m}$ length

2. From Node -1 to ESR at Bara (Zone-2): - Diameter proposed is $200 \mathrm{~mm}$ DI K-9 having $4022 \mathrm{~m}$ length.

3. From Node -1 to Node - 2:-Diameter proposed is 250 mm DI K-9 having 6502 m length.

4. From Node -1 to ESR at Bhageya (Zone-1): - Diameter proposed is $150 \mathrm{~mm}$ DI K-9 having $30 \mathrm{~m}$ length

5. From WTP to Node-1: - Diameter proposed is $250 \mathrm{~mm}$ DI K-9 having 2753 m length.

\subsubsection{Elevated/Ground Service Reservoir:}

The treated water is proposed to pump from Sump and Pump house to ESRs and GSR at different zones. The capacity is proposed to approximate $40 \%$ of demand (as per mass curve) for the immediate stage.

Table No: - 5.2.5 Details of ESR / GSR

\begin{tabular}{|c|c|c|c|c|}
\hline $\begin{array}{c}\text { Sr. } \\
\text { No. }\end{array}$ & $\begin{array}{c}\text { ESR / } \\
\text { GSR }\end{array}$ & $\begin{array}{c}\text { Capacity } \\
\text { (Lit) }\end{array}$ & $\begin{array}{c}\text { Staging } \\
\text { Height } \\
(\mathrm{m})\end{array}$ & GL (m) \\
\hline 1 & $\begin{array}{c}\text { ESR } \\
(\text { Zone-1) }\end{array}$ & $1,80,000$ & 21 & 486.874 \\
\hline 2 & $\begin{array}{c}\text { ESR } \\
(\text { Zone-2) }\end{array}$ & $4,70,000$ & 18 & 482.120 \\
\hline 3 & $\begin{array}{c}\text { GSR } \\
\text { (Zone 3) }\end{array}$ & $2,80,000$ & 3 & 538.320 \\
\hline
\end{tabular}




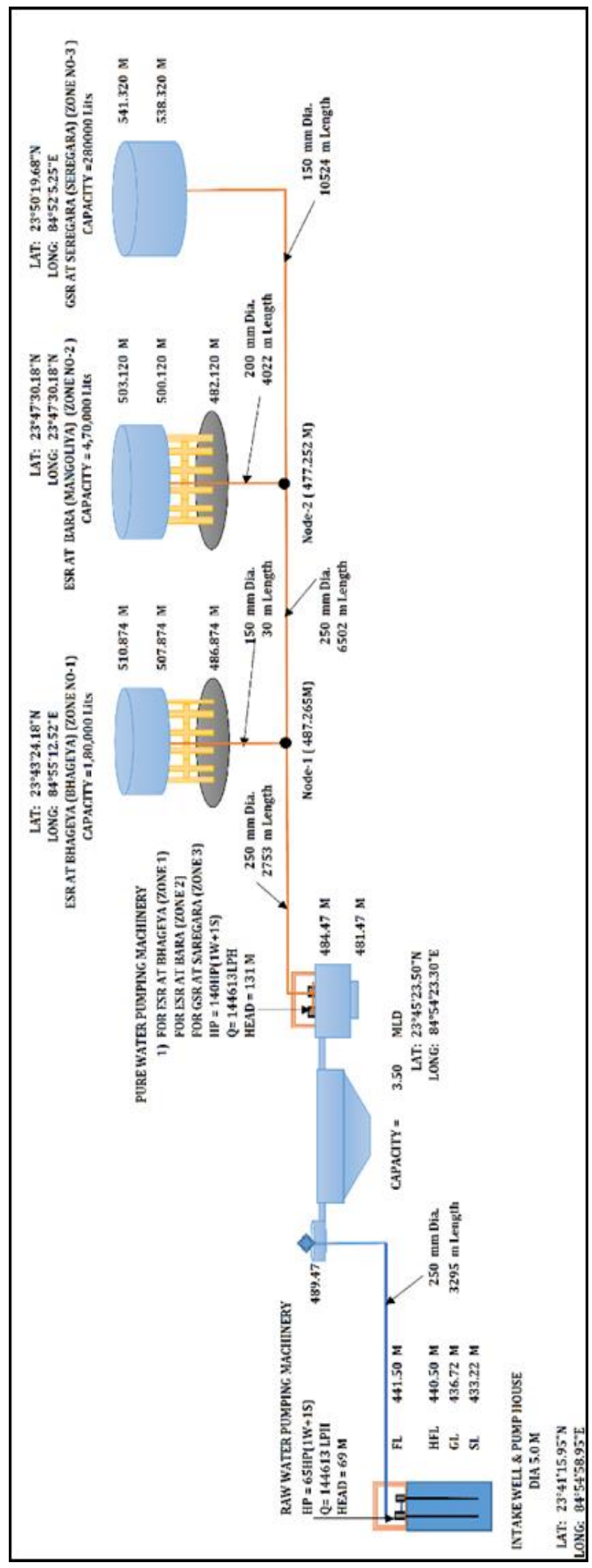

Figure No: 5.2. Schematic Diagram with Design Details

\subsubsection{Distribution System}

Analysis of the distribution system with the help of actual topographical survey and the WaterCAD software.

It is proposed to divide these zones as per topography. These zones will be served by the individual ESRs, whenever possible. In this scheme we have divided entire project area into three zones. These zones are -

Zone-I = Bhageya Panchayat, Murpa Panchayat.

Zone-II = Murpa Panchayat Marangloiya Panchayat, Bhageya Panchayat.

Zone-III = Seregara Panchayat, Ganeshpur Panchayat.

It proposed to lay the new distribution in the villages. The total distribution system will consist of DI K-7 pipes. The diameters for DI pipes will be very from $100 \mathrm{~mm}$ dia. to $300 \mathrm{~mm}$ dia.

\section{CONCLUSION}

The following conclusions can be drawn from the study: 1. The system has been tested on the field. The system's current findings suggest that it can save energy and money for the waterworks, ensure the security of the water supply system, and enhance water quality.

2. The treatment of raw water is planned to include aeration, filtration, and disinfection.

3. Reducing the overall efficiency of human consumption, material consumption, and water consumption is a goal that must be met.

4. The residual pressure is determined to be more than $7.00 \mathrm{~m}$ at all nodes. As a result, the flow will be smooth.

5. Even for complex types of networks, utilising technologies like WaterCAD, the study can be completed in a short period of time.

\section{REFERENCE}

[1] Dilip Babubhai Paneria (2017). - Analyzing the existing water distribution system of Surat using BentlysWatergems\|, International Journal of Advance Research in Engineering, Science Management.

[2] Prashant Virjibhai Vaghela, Sejal S. Bhagat (2013).Analysis of existing water distribution network by using Water GEMS a case study of Rajkot city.International Journal of Advance Research in Engineering, Science Management.

[3] Sumithra R.P., Nethaji Mariappan V.E., Joshua Amaranath (2013). - Feasibility analysis and design of WDS for Tiruunelveli Corporation using loop and watergems software International Journal on Applied Bioengineering, vol. 7, 1 January 2013.

[4] Sajedkhan S. Pathan., Dr. U. J. Kahalekar (2015).—Design of Optimal Water Supply Network and Its Water Quality Analysis by using Water GEM, Internation Journal Of Science and Research (IJSR) ISSN : 2319-7064.

[5] Rameshwari D. Bhoyar, Mr. S. J. Mane(2017), Modelling And Optimization Of Water Distribution System Site, 
International Journal of Advance Engineering and Research.

[6] Pravinkumar Shinde(2018), Design and Analysis of Water Distribution Network Using Water GEMS, International Journal of Advance Research in Engineering, Science \& Technology,

[7] Mukherjee, B. (2012). Pipeline design and analysis of distribution network of Dhapa water treatment plant, KMC International Journal of Advances in Science and Technology, 4(6), pp. 52-63

[8] CPHEEO., (1999). "Manual on Water Supply and Treatment." Published by Central Public Health Engineering, New Delhi, India.

[9] Garg Santosh Kumar.,(1992). "Water Supply Engineering: Environmental Engineering”, Nai Sarak, Delhi: Khannan Publication.

[10] Mays. L.W,(2000) "Water distribution system Handbook", McGraw Hill, New York 